\title{
THERMAL STRESS IN SELECTED MOUNTAIN SYSTEM IN CENTRAL AND EASTERN EUROPE - INITIAL RESEARCH BASED ON UTCI CHARACTERISTICS
}

\section{Krzysztof Błażejczyk ${ }^{1}$ (D) Milica Pecelj ${ }^{2,3}$ (D) $\bullet$ Pavol Nejedlik $^{4}$ (D) Olesya Skrynyk $^{5,6}$ (D) Katarina Mikulova ${ }^{7}$ (D)}

${ }^{1}$ Climate Impacts Laboratory, Institute of Geography and Spatial Organization Polish Academy of Sciences

Twarda 51/55, 00-818 Warsaw: Poland e-mail: k.blaz@twarda.pan.pl (corresponding author)

${ }^{2}$ Geographical Institute

Serbian Academy of Science and Arts Djure Jakšića 9, 11000 Belgrade: Serbia e-mail: milicapecelj@gmail.com

${ }^{3}$ Faculty of Philosophy

University of East Sarajevo

Alekse Šantića 1, 71420, Pale, RS: Bosnia and Herzegovina
${ }^{4}$ Earth Science Institute

Slovak Academy of Science

Dubravska cesta 9, 84005 Bratislava: Slovakia

e-mail: nejedlik@yahoo.com

${ }^{5}$ National University of Life and Environmental Sciences of Ukraine

Heroyiv Oborony, 15 Kyiv: Ukraine

${ }^{6}$ Ukrainian Hydrometeorological Institute, Nauky 37 Kyiv: Ukraine e-mail: skrynyk@nubip.edu.ua

${ }^{7}$ Slovak Hydrometeorological Institute Jeseniova 15, 83315 Bratislava: Slovakia e-mail: katarina.mikulova@shmu.sk

\begin{abstract}
Mountain areas create specific features of local climates (by modification of air circulation, insolation, air temperature, precipitation, wind regime) and greatly affect ambient weather conditions which influence different kinds of human (climbing, skiing, walking, etc.). However, till now only few studies of human bioclimate in individual mountain ridges in Europe were done. The aim of the present study is to assess thermal stress features represented by Universal Thermal Climate Index (UTCI) in nine mountain systems in Central and Eastern Europe. 37 meteorological stations located at altitudes of 237-3580 m above sea level were considered. The data represent midday observational term and cover the period 2000-2017. Mean, highest and lowest annual thermal stress values and annual frequency of cold and heat stress days are analysed The conducted studies have demonstrated that in the examined mountain systems thermal stress conditions are dependent (though to a various extent) mostly on altitude (UTCl values and heat stress days decrease and number of cold stress days rise significantly due to increase of altitude). However, impacts of latitude and longitude is well seen only in altitude belt of 300-1000 m a.s.l.
\end{abstract}

\section{Key words}

human bioclimate $\cdot$ UTCl $•$ mountain tourism potential $\cdot$ Central Europe $\cdot$ Eastern Europe 


\section{Introduction}

Mountains are important elements of regional and global climate systems. On the one hand they are influenced by global climate processes and on the other they modify air circulation, insolation, air temperature, precipitation and wind regime. Mountains are key areas for different kinds of human tourist and recreational activity (climbing, skiing, walking, etc.), which are greatly affected by ambient weather conditions. During the last decades tourist activity has been increasing all over the world. According to the United Nations World Tourism Organization, international arrivals have risen from 436 million in 1990 to 1401 million in 2018 (UNWTO, 2019). International tourism involves the necessity of sudden human adaptation to changed climatic conditions (de Freitas \& Grigorieva, 2009; Błażejczyk \& Vinogradova, 2014).

Due to their stimulating climate and attractive landscape, mountains are target areas for various groups of visitors both in warm and in cold seasons. Mountains have an important place in climatic and bioclimatic research because they significantly influence climate, not only of their own areas but also of their surroundings. They affect all meteorological variables (Trepińska, 2002; Migała, 2005; Niedźwiedź, 2012; Cheval et al., 2014; Spinoni et al., 2014; Rubel et al., 2017; Błażejczyk, 2019). Due to their elevation above sea level, mountains are a source of several modifications of various meteorological elements such as: air temperature (Baranowski, 2003b; Żmudzka, 2009, 2011; Dąbrowska \& Guzik, 2015), precipitation (Sindosi et al., 2015; Kholiavchuk \& Cebulska, 2019), cloud cover, solar radiation and insolation (Baranowski, 2003a; Matzarakis \& Katsoulis, 2006; Żmudzka \& Kulesza, 2019), wind speed and direction (Baranowski, 1999; Błażejczyk, 2019) and atmospheric phenomena (Niedźwiedź, 2003, 2006; Błażejczyk, 2019). Important factors that also affect the mountainous climate are geographical position and orientation of mountain ridges while they influence all meteorological elements, mostly solar radiation, air temperature and precipitation (Hess, 1965; Smith, 2015; Błażejczyk \& Skrynyk, 2019).

Lower temperature and higher wind speeds, which give a 'wind-chill' effect, cause the human body to be exposed to stronger thermal stress in those areas (Błażejczyk \& Sitek, 2003; Błażejczyk et al., 2013). Some research underline the role of continentality in creating climate features in transitional areas, both in lowland and mountain regions (Ciaranek, 2014; Vilček et al., 2016). A significant impact of continentality on thermal stress intensity in the northern Carpathians has been reported by Błażejczyk et al. (2020a, 2020b). They also found a strong influence of elevation above sea level and the exposure of a location (southward vs. northward) on $\mathrm{UTCl}$ values and frequency of thermal stress categories.

Up to now there have been only few papers presenting the biometeorological specificity of individual mountain areas in Europe (e.g. Gaijc-Čapka \& Zaninović, 1997; Głowicki, 2000; Harlfinger et al., 2004; Zaninović et al., 2006; Miszuk, 2008; Endler et al., 2010; Endler \& Matzarakis, 2011a, 2011b; Matzarakis et al., 2012; Błażejczyk et al., 2013, 2020a, 2020b; Milewski, 2013; Pecelj et al., 2017; Bokwa et al., 2019).

Throughout the last century a large number of indices have been proposed to define bioclimatic conditions, which are (or were) in use worldwide. The most frequently used indices (e.g. PT, PET, SET, WCI, WCT, Humidex, $\mathrm{HI}$, PST and many others) have been listed and discussed by Epstein and Moran (2006), Błażejczyk et al. (2012) and de Freitas and Grigorieva (2017). Temporal and spatial variability is one of the essential features of mountainous climate while people experience frequent changes of weather during a stay in mountains as reported by Zeng et al. (2020) for mountain regions of China-Pakistan border. Humans must adapt to changing weather stimuli. In general, an increase in differences in climate stimuli intensifies weather variability and the magnitude of adaptation processes in an organism (Jendritzky \& de Dear, 2008). 
These require to be prepared for changing weather stimuli during staying in any mountain (Miszuk et al., 2016; Acs et al., 2020).

There have been only few comparative studies of bioclimatic conditions in Europe (Błażejczyk \& McGregor, 2007; Błażejczyk et al., 2010, 2015; Błażejczyk \& Kunert, 2010; Błażejczyk \& Błażejczyk, 2014; Acs et al., 2020). The authors have reported an influence of geographical location (longitude and latitude) on bioclimatic features of studied cities. Recently, Błażejczyk et al. (2020) have compared the suitability of bioclimatic weather features for outdoor tourism in three European countries: Poland, Serbia and Ukraine. While general features of climate (e.g. air temperature, precipitation, cloudiness) in different mountain systems are compared in many research (e.g. Trepińska, 2002; Migała, 2005; Spinoni et al., 2014; Błażejczyk \& Skrynyk, 2019) then, there are no direct comparisons of the bioclimatic conditions in different mountain systems in Europe.
Therefore, the aim of the study is to present initial research dealing with the assessment of human bioclimate in different mountain systems in Central and Eastern Europe. While thermal features are of great importance of climate-tourism research the present paper concentrates on thermal stress in humans depending on elevation above sea level. The possible impact of geographical factors (latitude, longitude) is also discussed.

\section{Materials and methods}

The objects under study are nine mountain systems in Central and Eastern Europe (Fig. 1), namely: the Black Forest, northern Alps, central Alps, Sudetes, Western Carpathians, Eastern Carpathians, Dinaric Alps, Caucasus and southern Ural. In every area, depending on data availability, 3-7 meteorological stations were chosen. In total, 37 stations located at altitudes of 237-3580 m above sea level (m a.s.l.) were considered.

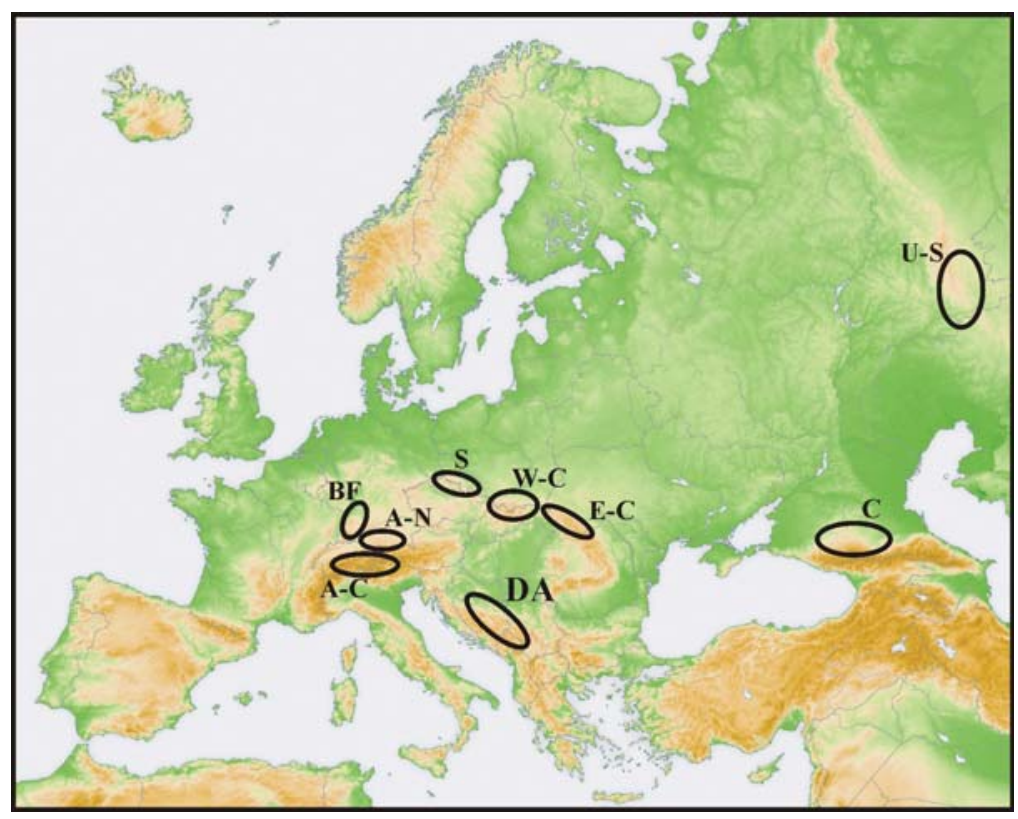

Figure 1. Mountain systems of Central and Eastern Europe considered in the research; explanations of abbreviations in Table 1

Source: own elaboration using map by San Jose - own map, based on the Generic Mapping Tools and ETOPO2, CC BY-SA 3.0, https://commons.wikimedia.org/w/index.php?curid=676986 
Table 1. Meteorological stations used in the study

\begin{tabular}{|c|c|c|c|c|}
\hline $\begin{array}{l}\text { Mountain system } \\
\text { (and abbreviation) }\end{array}$ & $\begin{array}{l}\text { Name of station } \\
\text { (and abbreviation) }\end{array}$ & $\begin{array}{l}\text { Latitude } \\
\text { (North) }\end{array}$ & $\begin{array}{l}\text { Longitude } \\
\text { (East) }\end{array}$ & $\begin{array}{l}\text { Elevation } \\
\text { (m a.s.l.) }\end{array}$ \\
\hline Black Forest (Bf) & $\begin{array}{l}\text { Freiburg }(\mathrm{FRB})^{1} \\
\text { Freudenstadt }(\mathrm{FRE})^{1} \\
\text { Feldberg }(\mathrm{FEL})^{1}\end{array}$ & $\begin{array}{l}48^{\circ} 01^{\prime} \\
48^{\circ} 27^{\prime} \\
48^{\circ} 00^{\prime}\end{array}$ & $\begin{array}{l}7^{\circ} 48^{\prime} \\
8^{\circ} 24^{\prime} \\
8^{\circ} 00^{\prime}\end{array}$ & $\begin{array}{r}237 \\
797 \\
1490\end{array}$ \\
\hline Northern Alps (A-N) & 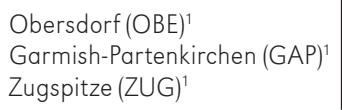 & $\begin{array}{l}47^{\circ} 27^{\prime} \\
47^{\circ} 29^{\prime} \\
47^{\circ} 24^{\prime}\end{array}$ & $\begin{array}{l}10^{\circ} 18^{\prime} \\
11^{\circ} 04^{\prime} \\
11^{\circ} 00^{\prime}\end{array}$ & $\begin{array}{r}806 \\
719 \\
2964\end{array}$ \\
\hline Central Alps (A-C) & $\begin{array}{l}\text { Interlaken }(I N T)^{2} \\
\text { Jungfraujoch }(J U N)^{2} \\
\text { Chur }(\mathrm{CHU})^{2} \\
\text { Weissfluhjoch }(\mathrm{WFJ})^{2} \\
\text { Engelberg }(\mathrm{ENG})^{2}\end{array}$ & $\begin{array}{l}46^{\circ} 40^{\prime} \\
46^{\circ} 33^{\prime} \\
46^{\circ} 52^{\prime} \\
46^{\circ} 50^{\prime} \\
46^{\circ} 49^{\prime}\end{array}$ & $\begin{array}{l}7^{\circ} 52^{\prime} \\
7^{\circ} 59^{\prime} \\
9^{\circ} 32^{\prime} \\
9^{\circ} 48^{\prime} \\
8^{\circ} 25^{\prime}\end{array}$ & $\begin{array}{r}580 \\
3580 \\
556 \\
2691 \\
1035\end{array}$ \\
\hline Sudetes (S) & $\begin{array}{l}\text { Kłodzko }(\mathrm{KLO})^{3} \\
\text { Jelenia Góra.(JEG) } \\
\text { Śnieżka }(\mathrm{SNI})^{3}\end{array}$ & $\begin{array}{l}50^{\circ} 27^{\prime} \\
50^{\circ} 54^{\prime} \\
50^{\circ} 44^{\prime}\end{array}$ & $\begin{array}{r}16^{\circ} 15^{\prime} \\
15^{\circ} 48^{\prime} \\
15^{\circ} 44^{\prime}\end{array}$ & $\begin{array}{r}356 \\
345 \\
1603\end{array}$ \\
\hline Western Carpathians (W-C) & $\begin{array}{l}\text { Zawoja }(\text { ZAW })^{3} \\
\text { Krynica }(\text { KRY })^{3} \\
\text { Zakopane }(\mathrm{ZAK})^{3} \\
\text { Hala Gasienicowa }(\mathrm{HAG})^{3} \\
\text { Lomnicky Stit }(\mathrm{LOS})^{4}\end{array}$ & $\begin{array}{l}49^{\circ} 37^{\prime} \\
49^{\circ} 25^{\prime} \\
49^{\circ} 17^{\prime} \\
49^{\circ} 14^{\prime} \\
49^{\circ} 12^{\prime}\end{array}$ & $\begin{array}{l}19^{\circ} 31^{\prime} \\
20^{\circ} 58^{\prime} \\
19^{\circ} 57^{\prime} \\
20^{\circ} 00^{\prime} \\
20^{\circ} 13^{\prime}\end{array}$ & $\begin{array}{r}720 \\
595 \\
857 \\
1520 \\
2635\end{array}$ \\
\hline Eastern Carpathians (E-C) & $\begin{array}{l}\text { Lviv }(\mathrm{LVI})^{5} \\
\text { Kolomya }(\mathrm{KOL})^{5} \\
\text { Pozhyzhevska }(\mathrm{POZ})^{5} \\
\text { Rakhiv }(\mathrm{RAK})^{5}\end{array}$ & $\begin{array}{l}49^{\circ} 48^{\prime \prime} \\
48^{\circ} 32^{\prime} \\
48^{\circ} 09^{\prime} \\
48^{\circ} 02^{\prime}\end{array}$ & $\begin{array}{l}23^{\circ} 58^{\prime} \\
25^{\circ} 03^{\prime} \\
24^{\circ} 32^{\prime} \\
24^{\circ} 11^{\prime}\end{array}$ & $\begin{array}{r}319 \\
298 \\
1451 \\
431\end{array}$ \\
\hline Dinaric Alps (Da) & $\begin{array}{l}\text { Bugoyno }(B \cup G)^{6} \\
\text { Sarayevo }(S A R)^{6} \\
\text { Livno (LIV) } \\
\text { Ivan-Sedlo (IVS) } \\
\text { Byaleshnica (BYA) } \\
\text { Vranje (VRA) } \\
\text { Zlatibor (ZLA) }\end{array}$ & $\begin{array}{l}44^{\circ} 03^{\prime} \\
43^{\circ} 52^{\prime} \\
43^{\circ} 42^{\prime} \\
43^{\circ} 45^{\prime} \\
43^{\circ} 42^{\prime} \\
42^{\circ} 33^{\prime} \\
43^{\circ} 44^{\prime}\end{array}$ & $\begin{array}{l}17^{\circ} 27^{\prime} \\
18^{\circ} 25^{\prime} \\
17^{\circ} 00^{\prime} \\
18^{\circ} 02^{\prime} \\
18^{\circ} 15^{\prime} \\
21^{\circ} 55^{\prime} \\
19^{\circ} 43^{\prime}\end{array}$ & $\begin{array}{r}562 \\
630 \\
724 \\
967 \\
2067 \\
435 \\
1030\end{array}$ \\
\hline Caucasus (C) & $\begin{array}{l}\text { Kislovodsk }(\text { KIS })^{8} \\
\text { Zelenchukskaya }(\text { ZEL) } \\
\text { Krasnaya Poljana }(\text { KRP) } \\
\text { Kluchovski Pereval(KLP) }\end{array}$ & $\begin{array}{l}43^{\circ} 54^{\prime} \\
43^{\circ} 52^{\prime} \\
43^{\circ} 41^{\prime} \\
43^{\circ} 15^{\prime}\end{array}$ & $\begin{array}{l}42^{\circ} 43^{\prime} \\
41^{\circ} 34^{\prime} \\
40^{\circ} 12^{\prime} \\
41^{\circ} 50^{\prime}\end{array}$ & $\begin{array}{r}943 \\
928 \\
566 \\
2037\end{array}$ \\
\hline $\begin{array}{l}\text { Southern Ural } \\
(U-S)\end{array}$ & $\begin{array}{l}\text { Ekaterinburg }(E K A)^{8} \\
\text { Tukan }(T U K)^{8} \\
\text { Verhneuralsk }(\text { VER })^{8}\end{array}$ & $\begin{array}{l}56^{\circ} 50^{\prime} \\
53^{\circ} 52^{\prime} \\
53^{\circ} 53^{\prime}\end{array}$ & $\begin{array}{l}60^{\circ} 38^{\prime} \\
57^{\circ} 25^{\prime} \\
59^{\circ} 12^{\prime}\end{array}$ & $\begin{array}{l}281 \\
551 \\
401\end{array}$ \\
\hline
\end{tabular}

Sources of meteorological data:

1 https://opendata.dwd.de/climate_environment/CDC/

${ }^{2}$ www.meteoschweiz.ch

${ }^{3}$ https://dane.imgw.pl/data/dane_pomiarowo_obserwacyjne/

${ }^{4}$ Slovak Hydrometeorological Institute (not available on-line)

${ }^{5}$ Ukrainian Hydrometeorological Institute (not available on-line)

${ }^{6}$ Federal Hydrometeorological Institute of Bosnia and Herzegovina (not available on-line)

${ }^{7}$ http://www.hidmet.gov.rs/latin/meteorologija/klimatologija_godisnjaci.php

${ }^{8}$ http://meteo.ru/english/climate/thmo.php 
In every mountain system the used stations show changes in thermal stress from their foothill up to the most elevated locations (Tab. 1). For every station daily meteorological data for the midday observational term were taken to calculate the Universal Thermal Climate Index. The data represent: air temperature, relative humidity, total cloud cover and wind speed at $10 \mathrm{~m}$ above ground. The data cover the period 2000-2017. While meteorological data were taken from meteorological services (Tab. 1) with different observational systems the common time for midday term occurs at 1 p.m. of local time.

To analyse thermal stress the Universal Thermal Climate Index (UTCl, Bröde et al., 2012; Fiala et al., 2012) was used. The UTCI is derived from the UTCl-Fiala model and is defined as the air temperature of the reference condition causing the same model response (understood as sweat production, shivering, skin wettedness, skin blood flow and rectal, face and mean skin temperatures) as the actual conditions. The model response is indicative of the physiological and thermoregulatory processes which are characteristic of the human reaction to neutral, moderate and extreme thermal conditions. The UTCl values are categorised in 10 classes (Tab. 2). To calculate UTCl, the BioKlima 2.6 software package was used (www. igipz.pan.pl/geoekoklimat/blaz/bioklima. $\mathrm{htm})$. The present research analyses the average (UTClavg), lowest (UTCImin) and highest (UTCImax) annual UTCl values and the frequencies of days with cold stress (CS_days, UTCl $<-13^{\circ} \mathrm{C}$ ) and heat stress (HS_days, $\mathrm{UTCl}>32^{\circ} \mathrm{C}$ ). The analysis concerns spatial distribution of thermal stress characteristics as well as their relationships to altitude,

Table 2. UTCl equivalent temperature categorized in terms of thermal stress

\begin{tabular}{|c|c|c|}
\hline UTCl $\left[{ }^{\circ} \mathrm{C}\right]$ range & Thermal stress category & Physiological responses \\
\hline$>46.0$ & extreme heat stress & $\begin{array}{l}\text { Increase in rectal temperature (Tre) time gradient. Steep } \\
\text { decrease in total net heat loss. Averaged sweat rate }>650 \mathrm{~g} / \mathrm{h} \text {, } \\
\text { steep increase. }\end{array}$ \\
\hline 38.1 to 46.0 & very strong heat stress & $\begin{array}{l}\text { Core to skin temperature gradient }<1 \mathrm{~K} \text { (at } 30 \mathrm{~min} \text { ). Increase } \\
\text { in Tre at } 30 \mathrm{~min} .\end{array}$ \\
\hline 32.1 to 38.0 & strong heat stress & $\begin{array}{l}\text { Dynamic Thermal Sensation (DTS) at } 120 \mathrm{~min}>+2 \text {. Averaged } \\
\text { sweat rate }>200 \mathrm{~g} / \mathrm{h} \text {. Increase in Tre. Instantaneous change } \\
\text { in skin temperature }>0 \mathrm{~K} / \mathrm{min} \text {. }\end{array}$ \\
\hline 26.1 to 32.0 & moderate heat stress & $\begin{array}{l}\text { Moderate increase in sweat rate, Tre and skin temperature: } \\
\text { mean }(T s k m) \text {, face }(T s k f c) \text {, hand }(T s k h n) \text {. Occurrence of sweating. } \\
\text { Steep increase in skin wettedness. }\end{array}$ \\
\hline 9.1 to 26.0 & no thermal stress & $\begin{array}{l}\text { DTS between }-0.5 \text { and }+0.5 \text { (averaged value). Latent heat } \\
\text { loss }>40 \mathrm{~W} \text {. Plateau in Tre time gradient. }\end{array}$ \\
\hline 0.1 to 9.0 & slight cold stress & DTS $<-1$. Local minimum of Tskhn (use gloves). \\
\hline-13.0 to 0.0 & moderate cold stress & $\begin{array}{l}\text { DTS }<-2 \text {. Vasoconstriction. Averaged } T s k f c<15^{\circ} \mathrm{C} \text { (pain). } \\
\text { Decrease in Tskhn. Tre time gradient }<0 \mathrm{~K} / \mathrm{h} \text {. Face skin tempera- } \\
\text { ture }<15^{\circ} \mathrm{C} \text { (pain). Tmsk time gradient }<-1 \mathrm{~K} / \mathrm{h} \text {. }\end{array}$ \\
\hline-27.0 to -13.1 & strong cold stress & $\begin{array}{l}\text { Averaged } T s k f c<7^{\circ} \mathrm{C} \text { (numbness). Tre time gradient }<-0.1 \mathrm{~K} / \mathrm{h} \text {. } \\
\text { Increase in core to skin temperature gradient. }\end{array}$ \\
\hline-40.0 to -27.1 & very strong cold stress & $\begin{array}{l}\text { Tskfc }<0^{\circ} \mathrm{C} \text { (frostbite). Steeper decrease in Tre. Tskfc }<7^{\circ} \mathrm{C} \\
\text { (numbness). Occurrence of shivering. } \\
\text { Tre time gradient }<-0.2 \mathrm{~K} / \mathrm{h} \text {. }\end{array}$ \\
\hline$<-40.0$ & extreme cold stress & 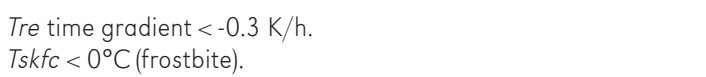 \\
\hline
\end{tabular}

Source: adapted from Błażejczyk et al. (2010) and Bröde et al. (2012) 
longitude and latitude of a station. Altitudinal gradients of UTCl characteristics were calculated for individual mountain systems.

Results of previous research (e.g. Hess, 1965; Rubel et al., 2017; Błażejczyk et al., 2020a) suggest that air temperature strongly depends on altitude. Thus, the UTCI changes due to longitude and latitude were analysed for the groups of stations located in relatively narrow altitudinal belts, namely: 300-500, $600-750,800-1000,1450-1600$ and 2650$2950 \mathrm{~m}$ a.s.l. The correlation coefficients of analysed relations were classified as follows: $<0.2$ - very weak, 0.2-0.39 - weak, 0.40.59 - moderate, 0.6-0.79 - strong and $\geq 0.8$ - very strong. The STATGRAPHICS Centurion $\mathrm{XVI}$ software package was used to verify statistical significance of relationships between altitude and UTCl characteristics.

\section{Results}

\section{Spatial variability of thermal stress characteristics}

Due to the broad geographical and altitudinal scope of the mountain stations studied, distinct spatial differentiation may be observed in the thermal stress characteristics. The lowest UTClavg and UTCImin values are seen in stations located high above sea level (ZUG, JUN, SNI, LOS, BYA). The lowest thermal stress is recorded in stations at the feet of the mountain ranges in question (Tab. 3). Considering all studied stations a distinct decrease in UTCl values may be observed with the increase in altitude (Fig. 2). For average UTCI values, altitudinal gradient (dUTClavg) is $-1.03^{\circ} \mathrm{C}$ per $100 \mathrm{~m}$ of elevation (the correlation coefficient $r$ between altitude and UTClavg is -0.78 and is statistically significant at significance level, $\mathrm{SL}=99 \%$ ). For UTCImin, altitudinal gradient (dUTCImin) is equal to $-1.23^{\circ} \mathrm{C} / 100 \mathrm{~m}$ $(r=-0.68, \mathrm{SL}=99 \%)$, and for UTCImax, $-0.72{ }^{\circ} \mathrm{C} / 100 \mathrm{~m}(\mathrm{r}=-0.89, \mathrm{SL}=99 \%)$. In the Caucasus, UTCl values are distinctly higher than in the remaining systems (Tab. 3) what can be caused by very south-eastern location opened to frequent advection of dry subtropical air masses. While altitudinal gradient of UTCImin is higher than gradients for UTClavg and UTCImax the correlation coefficient is the lowest. This is mostly seen at elevations $<1000 \mathrm{~m}$ a.s.l. Inside this altitudinal belt coline relief dominates (Rubel et al., 2017) and stations are situated in very different locations (bottoms of valleys, slopes with various elevation above bottoms). It cause great vulnerability to orographical cooling of air which affect also thermal stress conditions

With height above sea level, the number of cold stress days increases (Fig. 2) on average by 6.6 days $/ 100 \mathrm{~m}(r=0.77, \mathrm{SL}=99 \%)$. In the summit areas of the Alps, Carpathians and Dinaric Alps, there are over 185 such days per year. In the Caucasus cold stress days are rare, even at elevated stations. The number of heat stress days decreases on average by $0.53 / 100 \mathrm{~m}(\mathrm{r}=-0.46, \mathrm{SL}=99)$.
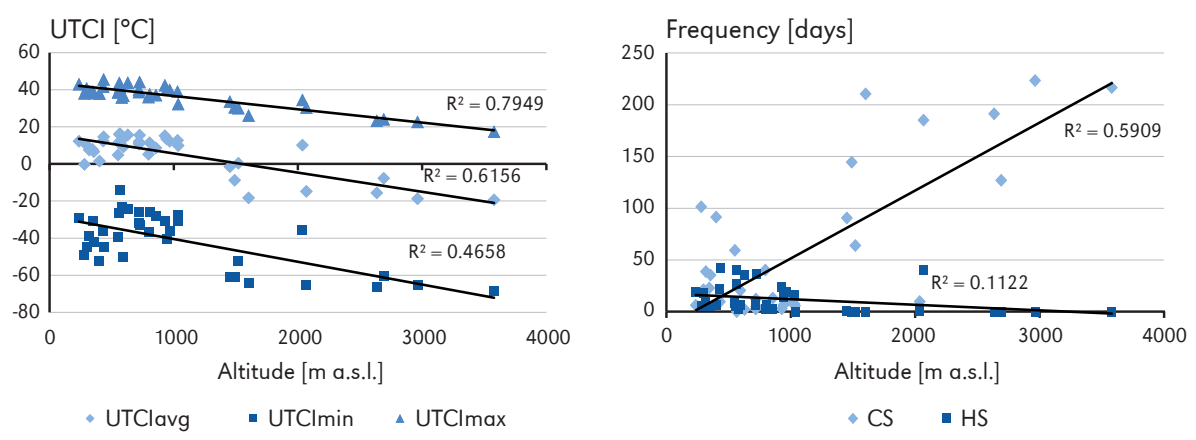

Figure 2. UTCl annual values (left panel) and frequency of different thermal stress categories: CS - cold stress days, HS - heat stress days (right panel) in Central and Eastern European mountain systems as a function of altitude 
Table 3. Annual characteristics of UTCI, 2000-2017

\begin{tabular}{|c|c|c|c|c|c|c|}
\hline \multirow{2}{*}{ Mountain system } & \multirow{2}{*}{ Station } & \multicolumn{3}{|c|}{$\begin{array}{l}\text { Annual UTCl values } \\
\qquad\left[{ }^{\circ} \mathrm{C}\right]\end{array}$} & \multicolumn{2}{|c|}{$\begin{array}{l}\text { Annual frequency of selected } \\
\text { UTCl categories [days] }\end{array}$} \\
\hline & & $\begin{array}{l}\text { average } \\
\text { (UTClavg) }\end{array}$ & $\begin{array}{l}\text { lowest } \\
\text { (UTCImin) }\end{array}$ & $\begin{array}{l}\text { highest } \\
\text { (UTCImax) }\end{array}$ & $\begin{array}{l}\text { cold stress } \\
\text { (CS_days) }\end{array}$ & $\begin{array}{l}\text { heat stress } \\
\text { (HS_days) }\end{array}$ \\
\hline \multirow[t]{3}{*}{ Black Forest } & FRB & 12.3 & -28.9 & 43.0 & 6.2 & 19.2 \\
\hline & FRE & 5.3 & -36.7 & 36.1 & 40.3 & 2.7 \\
\hline & FEL & -8.8 & -61.1 & 30.6 & 144.6 & 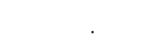 \\
\hline \multirow[t]{3}{*}{ Northern Alps } & OBE & 11.5 & -25.9 & 37.7 & 4.1 & 6.7 \\
\hline & GAP & 12.1 & -25.8 & 38.9 & 2.6 & 6.3 \\
\hline & ZUG & -18.8 & -65.1 & 22.7 & 223.5 & . \\
\hline \multirow[t]{5}{*}{ Central Alps } & INT & 12.8 & -23.3 & 35.8 & 2.9 & 2.7 \\
\hline & JUN & -19.3 & -68.7 & 17.5 & 216.7 & \\
\hline & $\mathrm{CHU}$ & 11.5 & -26.3 & 38.7 & 7.5 & 5.2 \\
\hline & WFJ & -7.7 & -60.3 & 24.2 & 127.1 & \\
\hline & ENG & 9.9 & -30.6 & 32.3 & 5.7 & 0.1 \\
\hline \multirow[t]{3}{*}{ Sudetes } & KLO & 6.8 & -42.3 & 38.2 & 35.3 & 5.4 \\
\hline &.$J E G$ & 7.7 & -30.9 & 39.1 & 23.0 & 5.2 \\
\hline & SNI & -18.3 & -64.3 & 26.1 & 210.6 & . \\
\hline \multirow[t]{5}{*}{ Western Carpathians } & ZAW & 10.9 & -32.0 & 40.1 & 12.2 & 7.9 \\
\hline & KRY & 9.2 & -49.9 & 36.8 & 20.7 & 6.2 \\
\hline & ZAK & 8.6 & -27.8 & 37.2 & 13.2 & 2.2 \\
\hline & HAG & 0.4 & -52.1 & 30.1 & 64.0 & . \\
\hline & LOS & -15.6 & -66.4 & 23.3 & 191.3 & \\
\hline \multirow[t]{4}{*}{ Eastern Carpathians } & LVI & 7.6 & -38.9 & 39.2 & 38.7 & 9.8 \\
\hline & $\mathrm{KOL}$ & 10.2 & -45.0 & 40.8 & 21.2 & 17.8 \\
\hline & POZ & -1.5 & -61.1 & 33.6 & 90.6 & 0.2 \\
\hline & RAK & 12.4 & -36.4 & 41.6 & 9.6 & 21.9 \\
\hline \multirow[t]{7}{*}{ Dinaric Alps } & $B \cup G$ & 16.0 & -26.4 & 43.8 & 4.1 & 41.8 \\
\hline & SAR & 15.7 & -24.1 & 43.9 & 2.2 & 37.5 \\
\hline & LIV & 15.5 & -33.1 & 44.3 & 5.1 & 38.9 \\
\hline & IVS & 12.3 & -36.3 & 40.0 & 10.8 & 19.7 \\
\hline & BYA & -14.7 & -65.4 & 30.4 & 185.1 & \\
\hline & VRA & 14.6 & -44.7 & 45.6 & 15.8 & 42.6 \\
\hline & ZLA & 12.8 & -27.8 & 39.0 & 7.4 & 16.6 \\
\hline \multirow[t]{4}{*}{ Caucasus } & KIS & 13.4 & -40.5 & 40.2 & 6.5 & 14.4 \\
\hline & ZEL & 15.2 & -30.9 & 42.4 & 2.8 & 23.6 \\
\hline & KRP & 16.2 & -13.9 & 41.3 & 0.1 & 26.5 \\
\hline & KLP & 10.1 & -35.5 & 34.6 & 9.7 & 0.9 \\
\hline \multirow[t]{3}{*}{ Southern Ural } & EKA & -0.2 & -48.9 & 38.1 & 101.3 & 5.2 \\
\hline & TUK & 4.9 & -39.5 & 38.7 & 59.4 & 8.7 \\
\hline & VER & 1.6 & -52.2 & 38.0 & 91.4 & 6.5 \\
\hline
\end{tabular}

Dot (.) indicate that heat stress days are not observed 
It should however be noted that in most stations above $1400 \mathrm{~m}$ a.s.l. such days practically do not occur. The exception is the Caucasus, the most south-eastern mountain system, where HS_days are recorded on average on 1 day per year (Tab. 3).

\section{Altitudinal gradients in individual mountain systems}

Altitudinal gradients of UTCl in the mountain systems studied differ. In the case of UTC-lavg values, the altitudinal gradient varies from $-0.4^{\circ} \mathrm{C} / 100 \mathrm{~m}$ in the northern Caucasus $(r=-0.96, \mathrm{SL}=99 \%)$ to $-1.9^{\circ} \mathrm{C} / 100 \mathrm{~m}$ in the Dinaric Alps ( $r=-0.95, \mathrm{SL}=99 \%)$ and $-2.0^{\circ} \mathrm{C} / 100 \mathrm{~m}$ in the Sudetes $(r=-0.99$, $\mathrm{SL}=95 \%)$. These gradients have statistical significance of at least $95 \%$. In the area of Alpine and northern Carpathian ranges, UTClavg altitudinal gradients are similar to each other and vary from -1.0 in the eastern Carpathians $(r=-0.92, S L=90 \%)$ to $1.4^{\circ} \mathrm{C} / 100 \mathrm{~m}$ in the northern Alps ( $r=-0.99$, SL 95\%) (Fig. 3).

Lowest UTCI values decrease with altitude more distinctly than average values: from $-1.5^{\circ} \mathrm{C} / 100 \mathrm{~m}$ in the Western Carpathians and in central Alps to $-2.0^{\circ} \mathrm{C} / 100 \mathrm{~m}$ in the Dinaric Alps. Higher values of dUTCImin were calculated for the Sudetes $(-2.2 \% / 100 \mathrm{~m})$ and the Black Forest $(-2.6 \% 100 \mathrm{~m})$, and lower ones, for the Caucasus $\left(-1.0^{\circ} \mathrm{C} / 100 \mathrm{~m}\right)$; however, they are not statistically significant. The smallest altitudinal gradients were seen for UTCImax and in each mountain system they are statistically significant. They varied from -0.5 in the Caucasus to $-1.0^{\circ} \mathrm{C} / 100 \mathrm{~m}$ in the Sudetes and Black Forest (Fig. 3).

The frequency of cold stress days and heat stress days also change with altitude. In the case of cold stress, altitudinal gradient (dCS) increases from around 5.9 days $/ 100 \mathrm{~m}$ in the
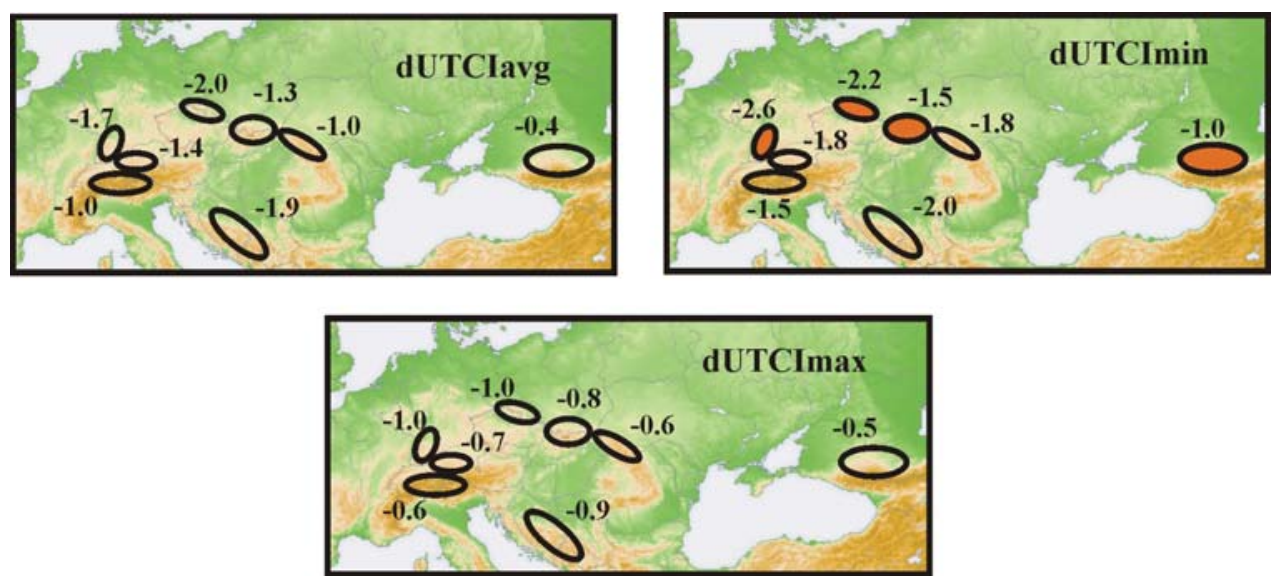

Figure 3. Altitudinal gradients $\left({ }^{\circ} \mathrm{C} / 100 \mathrm{~m}\right)$ of various $\mathrm{UTCl}$ values in studied mountain systems; circles filled in orange indicate insignificant values
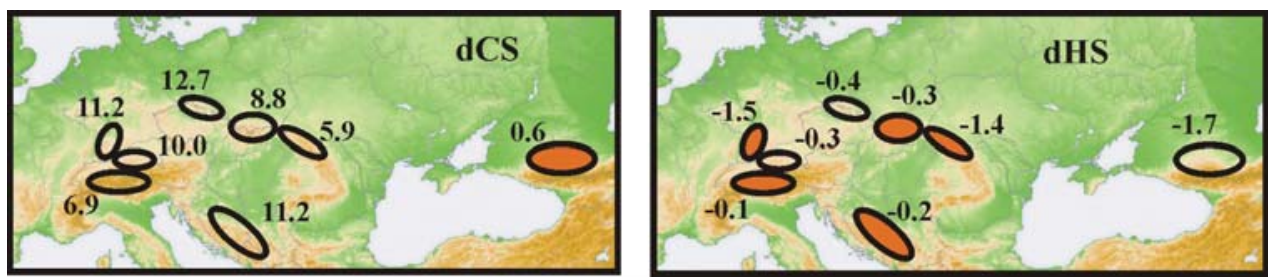

Figure 4. Altitudinal gradients of cold stress (CS) and heat stress (HS) frequency; circles filled in orange indicate insignificant values 
Eastern Carpathians to 12.7 days/100 m in the Sudetes. Only in the Caucasus is dCS statistically insignificant. As mentioned before, the number of heat stress days' decreases with altitude (from -0.12 in the central Alps to -1.71 days/100 m in the Caucasus), but in most of the studied mountain ranges $\mathrm{dHS}$ are statistically insignificant or weakly significant (Fig. 4).

\section{Changes of UTCl due to latitude and longitude}

Latitude is geographical factor that impacts thermal and radiative features of climate and longitude influence mainly frequency of oceanic and continental air masses with different features of temperature and humidity. Relatively narrow extent of latitude and longitude of examined mountain systems allowed only for initial analysis of possible impacts of geographical location of stations on UTCl characteristics. Thus, to eliminate evident influence of elevation a.s.l. such impacts were studied separately within 5 narrow altitudinal belts (Tab. 4).
Within altitudinal belt of $300-500 \mathrm{~m}$ a.s.l. 7 stations quite well represent wide spectrum of latitude $\left(42.6-53.9^{\circ} \mathrm{N}\right)$ and longitude (15.8-59.2 $\left.{ }^{\circ} \mathrm{E}\right)$. There is very distinct (indicated by strong and very strong correlation coefficients) decrease in UTClmax, UTClavg and frequency of HS_days from southern to northern locations. On the other hand number of CS_days increase when moving from south to north. Considering longitudinal changes of UTCI the strong decrease in UTCImin and very strong increase in CS_days is observed when moving from west to east. Weak or very weak correlation was found for latitude vs. UTCImin and longitude vs UTCImax and HS_days. While in this belt meteorological stations are situated mainly in valleys' bottoms and lower parts of slopes weak correlation is perhaps caused by impacts of another factors like slope exposure or occurrence of cold air lakes in valleys.

6 stations within belt of $600-750 \mathrm{~m}$ a.s.l. cover latitudes from 43.7 to $49.6^{\circ} \mathrm{N}$ and longitudes from 7.9 to $21.0^{\circ} \mathrm{E}$. Increase in latitude caused strong and very strong decrease in case of UTCImax, UTClavg and HS_days.

Table 4. Correlation coefficients between latitude and longitude and various UTCl characteristics

\begin{tabular}{|c|c|c|c|c|c|c|}
\hline $\begin{array}{c}\text { Altitudinal belt } \\
\text { [m a.s.l. }]\end{array}$ & $\begin{array}{l}\text { Number } \\
\text { of stations }\end{array}$ & UTCImin & UTClavg & UTCImax & CS_days & HS_days \\
\hline \multicolumn{7}{|c|}{ Latitude vs. UTCl characteristics } \\
\hline $300-500$ & 7 & -0.311 & -0.935 & -0.959 & +0.723 & -0.935 \\
\hline $600-750$ & 6 & -0.491 & -0.971 & -0.720 & +0.707 & -0.860 \\
\hline 800-1000 & 8 & +0.324 & -0.837 & -0.656 & +0.501 & -0.890 \\
\hline $1450-1600$ & 4 & -0.179 & -0.644 & -0.887 & +0.469 & . \\
\hline $2650-2950$ & 3 & -0.816 & -0.454 & -0.331 & +0.409 & . \\
\hline \multicolumn{7}{|c|}{ Longitude vs. UTCI characteristics } \\
\hline $300-500$ & 7 & -0.744 & -0.632 & -0.281 & +0.869 & -0.172 \\
\hline $600-750$ & 6 & -0.663 & -0.167 & +0.416 & +0.667 & +0.356 \\
\hline $800-1000$ & 8 & -0.362 & +0.713 & +0.777 & -0.417 & +0.689 \\
\hline $1450-1600$ & 4 & +0.279 & +0.528 & +0.423 & -0.532 & . \\
\hline $2650-2950$ & 3 & -0.738 & -0.339 & -0.210 & +0.291 & . \\
\hline \multicolumn{7}{|c|}{ Correlation coefficient: } \\
\hline very weak & weak & & erate & strong & & \\
\hline
\end{tabular}


Strong correlation is also noted for increased trend in CS_days due to latitude increase. Impact of longitude on UTCI characteristics is weak or very weak. Only for UTCImin and CS_days correlation is moderate.

8 stations characterise changes in UTCI within altitudinal belt of $800-1000 \mathrm{~m}$ a.s.l. They are located within latitude of 43.7$49.3^{\circ} \mathrm{N}$ and longitude of $8.4-42.7^{\circ} \mathrm{E}$. Strong and very strong correlation is observed for majority of UTCl characteristics: decrease of UTCImax, UTClavg and HS days due to rise of latitude as well as increase of the same measures due to longitude. Correlation for UTCImin and CS_days is rather weak.

Geographical extent of 4 stations situated within altitudinal belt of $1450-1600 \mathrm{~m}$ a.s.l. is very narrow $\left(48.0-50.7^{\circ} \mathrm{N}\right.$ in latitude and $8.0-24.5^{\circ} \mathrm{E}$ in longitude). Thus UTCI trends observed in this belt are only initial. Strong and very strong negative correlation was found for relations between latitude and UTCImax and UTClavg. For longitude correlations are mostly weak and very weak.

Small number of station within belt of 2650-2950 m a.s.l. (only 2 in Alps and 1 in Western Carpathians) allows for very preliminary analysis. Only UTCImin shows strong and very strong negative dependence from increasing values of latitude and longitude. This suggests that lowest values of UTCl decrease when moving to north and to west.

\section{Discussion}

Research of mountain climate provide important information about specific spatial changes of particular meteorological elements. Many research refer decrease of air temperature due increase of elevation above sea level (Głowicki, 2000; Trepińska, 2002; Migała, 2005; Cheval et al., 2014; Błażejczyk, 2019; Łupikasza \& Szypuła, 2019). However, such decrease has different intensity in concave and convex forms of relief and in dependence of slope exposure (Hess, 1965). While UTCI strongly depend on air temperature the vertical differentiation of thermal stress is also evident. For northern Carpathians
Błażejczyk et al. (2020a) have found significant changes of UTCl due to elevation a.s.l. However, the changes have different intensity at northward and southward slopes. They also reported great influence of air circulation on thermal stress in Carpathians (Błażejczyk et al., 2020b). It seems that exposure of mountain systems to different air circulation patterns can be one of causes of different altitudinal UTCl gradients in regions considered in this paper.

However, the common feature of mountain systems is acceleration of cold stress or cold thermal sensation according to increase of altitude (Harlfinger et al., 2004; Zaninović et al., 2006; Miszuk, 2008; Endler et al., 2010; Pecelj et al., 2017). This feature is of great importance in assessing touristic and recreational potential of mountain areas (Miszuk et al., 2016; Acs et al., 2020). The increasing cold stress in elevated locations is a handicap for active tourism (climbing, jogging etc.) with reduced risk of organism overheating involved by great metabolism. On the other hand cold stress at elevated locations, accelerated by strong winds, is unsuitable for passive recreation forms like sun and air bathing (Błażejczyk \& Sitek, 2003; Błażejczyk \& Kunert, 2010; Miszuk et al., 2016; Błażejczyk et al., 2020).

In present research we have found different patterns of latitudinal and longitudinal changes of various thermal stress characteristics. While in lower altitudes UTCl gradients have similar directions as those observed by Błażejczyk and Błażejczyk (2014) than in elevated locations such changes are less visible. It seems, that thermal stress at high summits is mostly affected by elevation and not by geographical location. However, this point needs detail research in the future with the using of extended number of summit stations located in different locations.

Altitudinal changes in thermal stress referred in present paper are in accordance with research of climate zonation of mountain areas done by Hess (1965) for Western Carpathians, Niedźwiedź (2012) for Eastern Carpathians and by Rubel et al. (2017) for Alps. 


\section{Conclusions}

This paper presents initial results of research on bioclimatic conditions in the mountains of Europe. We considered here only one feature of bioclimate, i.e. thermal stress. The picture of altitudinal impacts on thermal stress is clear (decreasing of UTCl values and heat stress frequency as well as rise of cold stress days due to increase of altitude) but differs between mountain systems.

Impact of latitude and longitude on thermal stress in elevated parts of mountains is not so evident as altitude. To solve this problem there is necessary to broaden the data base, particularly for elevated locations (high ridges and summits).
Our research shows significant differences in thermal stress characteristics between various mountain systems. To explain them the detail analysis of seasonal features of bioclimate are necessary, including air circulation variability.

The paper presents only the average annual thermal stress characteristics. Future studies should also cover seasonal and daily variability of bioclimatic conditions. This will allow for complex assessment of mountainous areas with respect to various practical human needs, chiefly tourism and recreation.

\section{Editors' note:}

Unless otherwise stated, the sources of tables and figures are the authors', on the basis of their own research.

\section{References}

Acs, F., Zsákai, A., Kristóf, E., Szabó, A.I., Breuer, H. (2020). Human thermal climate of the Carpathian Basin. International Journal of Climatology, 1-14. https://doi.org/10.1002/joc.6816

Baranowski, J. (1999). Wpływ rzeźby i pokrycia terenu na warunki wietrzne w Tatrach Wysokich na przykładzie Hali Gasienicowej. In A. Kotarba, A. Kozłowska (Eds.), Badania geoekologiczne w otoczeniu Kasprowego Wierchu (pp. 105-120), Prace Geograficzne, 174, Wrocław: IGiPZ PAN; Continuo.

Baranowski, J. (2003a). Pochłonięte promieniowanie słoneczne w Tatrach w otoczeniu Hali Gasienicowej. In K. Błażejczyk, B. Krawczyk, M. Kuchcik (Eds.), Postępy w badaniach klimatycznych i bioklimatycznych (pp. 131-144), Prace Geograficzne, 188, Warsaw: IGiPZ PAN.

Baranowski, J. (2003b). Dynamika zmian dobowych i zróżnicowanie przestrzenne temperatury powietrza na Hali Gqsienicowej. Przeglad Geograficzny, 75(2), 271-286.

Błażejczyk, A., Pecelj, M., Skrynyk, O., Błażejczyk, K., Skrynyk, O. (2020). Weather suitability for outdoor tourism in three European regions in first decades of 21 st century. International Journal of Biometeorology. https://doi.org/10.1007/s00484-020-01984-z

Błażejczyk, K. (2019). Sezonowa i wieloletnia zmienność niektórych elementów klimatu w Tatrach i Karkonoszach w latach 1951-2015. Przegląd Geograficzny, 91(1), 59-80. https://doi.org/10.7163/PrzG.2019.1.2

Błażejczyk, K., Baranowski, J., Błażejczyk, A., Szmyd, J. (2013). Klimat i bioklimat Hali Gąsienicowej. In Z. Rączkowska, A. Kotarba (Eds.), Dolina Suchej Wody w Tatrach. Środowisko i jego wspótczesne przemiany (pp. 67-95). Prace Geograficzne, 239, Warsaw: IGiPZ PAN.

Błażejczyk, K., Baranowski, J., Jendritzky, G., Błażejczyk, A., Bröde, P., Fiala, D. (2015). Regional features of the bioclimate of Central and Southern Europe against the background of the Köppen-Geiger climate classification. Geographia Polonica, 88(3), 439-453. https://doi.org/10.7163/GPol.0027

Błażejczyk, K., Błażejczyk, A. (2014). Assessment of bioclimatic variability on regional and local scales in Central Europe using UTCI. Scientific Annals of "Alexandru loan Cuza" University of IASI, vol. LX, no. I, s. I/ c, Geography series, 67-82. 
Błażejczyk, K., Bröde, P., Fiala, D., Havenith, G., Holmér, I., Jendritzky, G., Kampmann, B., Kunert, A. (2010). Principles of the new Universal Thermal Climate Index (UTCI) and its application to bioclimatic research in European scale. Miscelanea Geographica, 14, 91-102. https://doi.org/10.2478/mgrsd-2010-0009

Błażejczyk, K., Epstein, Y., Jendritzky, G., Staiger, H., Tinz, B. (2012). Comparison of UTCl to selected thermal indices. International Journal of Biometeorology, 56(3), 515-535. https://doi.org/10.1007/s00484-011-0453-2

Błażejczyk, K., Kunert, A. (2010). Obciążenie cieplne organizmu człowieka podczas letnich i zimowych wędrówek po Tatrach. In Z. Krzan (Ed.), Nauka a Zarzadzanie obszarem Tatr i ich otoczeniem (pp. 61-68), Materiały IV Konferencji Przyroda Tatrzańskiego Parku Narodowego a Człowiek, 14-16.10.2010. Zakopane, Tatrzański Park Narodowy.

Błażejczyk, K., McGregor, G. (2007). Warunki biotermiczne a umieralność w wybranych aglomeracjach europejskich. Przeglad Geograficzny, 79(3-4), 401-423.

Błażejczyk, K, Nejedlik, P, Skrynyk, O, Halaś, A, Skrynyk, O, Błażejczyk, A, Mikulova, K. (2020a). Influence of geographical factors on thermal stress in northern Carpathians. International Journal of Biometeorology. https://doi.org/10.1007/s00484-020-02011-x

Błażejczyk, K., Nejedlik, P., Skrynyk, O., Halaś, A., Skrynyk, O., Baranowski, J., Mikulova, K. (2020b). Thermal stress in northern Carpathians and air circulation. Miscellanea Geographica, 24(3), 147-160. https://doi.org/10.2478/mgrsd-2020-0022

Błażejczyk, K., Sitek, M. (2003). La temperature ressentie par les touristes en montagne en été. In K. Błażejczyk, A.B. Adamczyk (Eds.), Les relations Climat-Homme-Climat (pp. 61-64). Dokumentacja Geograficzna, 29, Warsaw: IGiPZ PAN.

Błażejczyk, K., Skrynyk, O. (2019). Principal features of Chornohora climate (Ukrainian Carpathians). Bulletin of Geography. Physical Geography Series, 17(1), 61-76. https://doi.org/10.2478/bgeo-2019-0015

Błażejczyk, K., Vinogradowa, V. (2014). Adaptation Strain Index for tourists traveling from central and northern Europe to the Mediterranean. Finisterra, 49(98), 139-157. https://doi.org/10.18055/Finis6465

Bokwa, A., Murzyn, P., Krzaklewski, P., Kukułka, W., Fijał, S. (2019). Wpływ zmian klimatu na intensywność bodźców bioklimatycznych w Polskich Karpatach Zachodnich w okresie letnim. In L. Kolendowicz, E. Bednorz, A.M. Tomczyk (Eds.), Zmienność klimatu Polski i Europy oraz jej cyrkulacyjne uwarunkowania (pp. 71-86). Poznań: Bogucki Wydawnictwo Naukowe.

Bröde, P., Fiala, D., Błażejczyk, K., Holmér, I., Jendritzky, G., Kampmann, B., Tinz, B., Havenith, G. (2012). Deriving the operational procedure for the Universal Thermal Climate Index (UTCI). International Journal of Biometeorology, 56(3), 481-494. https://doi.org/10.1007/s00484-011-0454-1

Cheval, S., Birsan, M.V., Dumitrescu, A. (2014). Climate variability in the Carpathian Mountains Region over 1961-2010. Global and Planetary Change, 118, 85-96. https://doi.org/10.1016/j.gloplacha.2014.04.005

Ciaranek, D. (2014). Variability of the thermal continentality index in Central Europe. Aerul si Apa, Componente ale Mediului, 307-313.

Dąbrowska, K., Guzik, M. (Eds.). (2015). Atlas of the Tatry Mountains. Abiotic nature. Zakopane: Tatra National Park.

Endler, Ch., Matzarakis, A. (2011a). Climate and tourism in the Black Forest during the warm season. International Journal of Biometeorology, 55, 173-186. https://doi.org/10.1007/s00484-010-0323-3

Endler, Ch., Matzarakis, A. (2011b). Climatic potential for tourism in the Black Forest, Germany - winter season. International Journal of Biometeorology, 55, 339-351. https://doi.org/10.1007/s00484-010-0342-0

Endler, Ch., Oehler, K., Matzarakis, A. (2010). Vertical gradient of climate change and climate tourism conditions in the Black Forest. International Journal of Biometeorology, 54, 45-61. https://doi.org/10.1007/s00484-009-0251-2

Epstein, Y., Moran, D.S. (2006). Thermal comfort and heat stress indices. Industrial Health, 44, 388-398. https://doi.org/10.2486/indhealth.44.388 
Fiala, D., Havenith, G., Bröde, P., Kampmann, B., Jendritzky, G. (2012). UTCl-Fiala multi-node model of human heat transfer and temperature regulation. International Journal of Biometeorology, 56, 429-441. https://doi.org/10.1007/s00484-011-0424-7

Freitas de, Ch., Grigorieva, E. (2009). The Acclimatization Thermal Strain Index (ATSI): A preliminary study of the methodology applied to climatic conditions of the Russian Far East. International Journal of Biometeorology, 53, 307-315. https://doi.org/10.1007/s00484-009-0215-6

Freitas de, Ch., Grigorieva, E. (2017). A comparison and appraisal of a comprehensive range of human thermal climate indices. International Journal of Biometeorology, 61, 487-512. https://doi.org/10.1007/s00484-016-1228-6

Gajic-Čapka, M., Zaninović, K. (1997). Changes in temperature extremes and their possible causes at the SE boundary of the Alps. Theoretical and Applied Climatology, 57, 89-94. https://doi.org/10.1007/BF00867979

Głowicki, B. (2000). 20th century variability to daily maxima and minima of air temperature in the Sudetic Mountains. Geographia Polonica, 73(2), 111-116.

Harlfinger, O., Pilger, H., Rieder, H., Kock, M., Pichler-Semmelrock, F.P. (2004). Spatial and seasonal distribution of bioclimatic indices in the state of Styria as a basis for holiday planning. Hrvatski meteoroloski časopis, 39, 103-119.

Hess, M. (1965). Piętra klimatyczne w Polskich Karpatach Zachodnich. Zeszyty Naukowe UJ, Prace Geograficzne, 11.

Jendritzky, G., de Dear, R. (2008). Adaptation and the thermal environment. In K.L. Ebi, I. Burton, G. McGregor (Eds.), Biometeorology for adaptation to climate variability and change: Research frontiers and perspectives (pp. 9-32). Heidelberg: Springer.

Kholiavchuk, D., Cebulska, M. (2019). The highest monthly precipitation in the area of the Ukrainian and the Polish Carpathian Mountains in the period from 1984 to 2013. Theoretical and Applied Climatology, 138, 1615-1628. https://doi.org/10.1007/s00704-019-02910-z

Łupikasza, E., Szypuła, B. (2019). Vertical climatic belts in the Tatra Mountains in the light of current climate change. Theoretical and Applied Climatology, 136, 249-264. https://doi.org /10.1007/s00704-018-2489-2

Mateeva, Z., Filipov, A. (2003). Bioclimatic distance index in the Rila-and-Rhodopy area of Bulgaria. In K. Błażejczyk, B. Krawczyk, M. Kuchcik (Eds.), Postępy w badaniach klimatycznych i bioklimatycznych (pp. 295-302), Prace Geograficzne, 188, Warsaw: IGiPZ PAN.

Matzarakis, A., Hämmerle, M., Koch, E., Rudel, E. (2012). The climate tourism potential of Alpine destinations using the example of Sonnblick, Rauris and Salzburg. Theoretical and Applied Climatology, 110, 645-658. https://doi.org/10.1007/s00704-012-0686-y

Matzarakis, A., Katsoulis, V.D. (2006). Sunshine duration hours over the Greek region. Theoretical and Applied Climatology, 83, 107-120. https://doi.org/10.1007/s00704-005-0158-8

Migała, K. (2005). Piętra klimatyczne w górach Europy a problem zmian globalnych. Acta Universitatis Wratislaviensis, 2718, Studia Geograficzne, 78, Wrocław: Uniwersytet Wrocławski.

Milewski, P. (2013). Application of the UTCI to the local bioclimate of Poland's Ziemia Kłodzka region. Geographia Polonica, 86(1), 47-54. https://doi.org/10.7163/GPol.2013.6

Miszuk, B. (2008). Charakterystyka warunków bioklimatycznych w Karkonoszach z punktu widzenia różnych form turystyki i rekreacji. Prace Geograficzne IGiGP UJ, 120, 79-91.

Miszuk, B., Otop, I., Strońska, M., Schwarzak, S., Surke, M. (2016). Tourism-climate conditions and their future development in the Polish-Saxon border area. Meteorologische Zeitschrift, 25(4), 421-434. https://doi.org/10.1127/metz/2016/0700

Niedźwiedź, T. (2003). Extreme precipitation events on ten northern side of the Tatra Mountains. Geographia Polonica, 76(1), 13-21. 
Niedźwiedź, T. (2006). Zmiany temperatury powietrza w Tatrach w porównaniu do Karpat Południowych i Tatr. In A. Kotarba, W. Borowiec (Eds.), Tatrzański Park Narodowy na tle innych górskich terenów chronionych. T. 1, Nauki o Ziemi (pp. 13-21). Zakopane - Kraków: Tatrzański Park Narodowy.

Niedźwiedź, T. (2012). Climate. In D. Lóczy, M. Stankoviansky, A. Kotarba (Eds.), Recent landform evolution: The Carpatho-Balcan-Dinaric region (pp. 19-29). Springer: Dordrecht. https://doi.org/10.1007/978-94-007-2448-8_2

Pecelj, M., Dordević, D., Pecelj, M.R., Pecelj-Purković, J., Filipović, D., Šećerov, V. (2017). Biothermal conditions on Mt. Zlatibor based on thermophysiological indices. Archives of Biological Sciences, 69(3), 455-461. https://doi.org/10.2298/ABS151223120P

Rubel, F., Brugger, K., Haslinger, K., Auer, I. (2017). The climate of the European Alps: Shift of very high resolution Köppen-Geiger climate zones 1800-2100. Meteorologische Zeitschrift, 26(2), 115-125. https://doi.org/10.1127/metz/2016/0816

Sindosi, O.A., Bartzokas, A., Kotroni, V., Lagouvardos, K. (2015). Influence of orography on precipitation amount and distribution in NW Greece. A case study. Atmospheric Research, 152, 105-122. https://doi.org/10.1016/j.atmosres.2014.06.013

Smith, R.B. (2015). Mountain meteorology. Overview. In G.R. North, J. Pyle, F. Zhang, Encyclopedia of Atmospheric Sciences (pp. 57-61), Amsterdam: Elsevier.

Spinoni, J., Szalai, S., Szentimrey, T., Lakatos, M., Bihari, Z., Nagy, A., Németh, Á., Kovács, T., Mihić, D., Dacić, M., Petrović, P., Kržič, A., Hiebl, J., Auer, I., Milković, J., Štepánek, P., Zahradníček, P., Kilar, P., Limanówka, D., ... Vogt, J. (2014). Climate of the Carpathian Region in the period 1961-2010: climatologies and trends of 10 variables. International Journal of Climatology, 35(7), 1322-1341. https://doi.org/10.1002/joc.4059

Trepińska, J. (2002). Górskie klimaty. Kraków: Wydawnictwo IGiGP UJ.

UNWTO. (2019). International Tourism Highlights, 2019 Edition. https://www.unwto.org/publication/international-tourism-highlights-2019-edition

Vilček, J., Škvarenina, J., Vido, J., Nalevanková, P., Kandrík, R., Škvareninová, J. (2016). Minimal change of thermal continentality in Slovakia within the period 1961-2013. Earth System Dynamics, 7, 735-744. https://doi.org/10.5194/esd-7-735-2016

Zaninović, K., Matzarakis, A., Cegnar, T. (2006). Thermal comfort trends and variability in the Croatian and Slovenian mountains. Meteorologische Zeitschrift, 15(2), 243-251. https://doi.org/10.1127/0941-2948/2006/0119

Zeng, D., Wu, J., Mu, Y., Deng, M., Wei, Y., Sun, S. (2020). Spatial-temporal pattern changes of UTCl in the China-Pakistan economic corridor in recent 40 years. Atmosphere, 11, 858. https://doi.org/10.3390/atmos11080858

Żmudzka, E. (2009). Changes of thermal conditions in the Polish Tatra Mountains. Landform Analysis, 10, 140-146.

Żmudzka, E. (2011). Contemporary climate changes in the high mountain part of the Tatras. Miscellanea Geographica, 15, 93-102. https://doi.org/10.2478/v10288-012-0005-6

Żmudzka, E., Kulesza, K. (2019). Total solar radiation in Zakopane and at mount Kasprowy Wierch in 1986-2015. Geographia Polonica, 92(2), 211-231. https://doi.org/10.7163/GPol.0145 